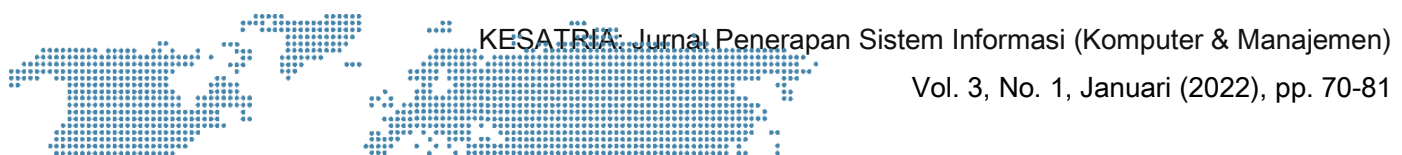

\title{
Pembangunan Sistem Informasi E-Voting Pada Universitas XYZ
}

\author{
蜶: \\ Muhemnated Nur Syansum in ${ }^{1}$, Yuyun Tri Wiranti ${ }^{2}$, M. Ihsan Alfani Putera ${ }^{3}$ \\ Program Studi Sisem Informasi, Institut Teknologi Kalimantan \\ Jitan Soekarno Hatta KM. 15, Balikpapan, Kalimantan Timur \\ 10171051@student.itk.ac.id
}

\begin{abstract}
An organization is a group of people who have a common goal, where everyone has the same goals so that they are combined and are expected to achieve goals together. The organization itself has a membership structure that functions to divide the tasks of each individual and each organization has a leader who functions to regulate the running of the organization. At the XYZ University, there are various organizations that all students can participate in. The head of the organization is chosen from the election activities held every year to continue the baton of management. There are several obstacles experienced when conducting election activities, namely, election activities are carried out offline, due to pandemic conditions so that election activities cannot be carried out, there are many invalid ballots, and also the vote counting process which takes quite a long time. In addition to obstacles during the election, election activities also cost quite a lot to print ballots and so on to launch elections. Therefore, this research was conducted by building an e-voting information system. The e-voting system itself has several advantages compared to elections conducted offline. It is hoped that the e-voting system can reduce errors made in offline elections. The system development uses the Personal Extreme Programming (PXP) method using the Laravel framework. It is hoped that the system built can assist the voting process in election activities at the XYZ Universty.
\end{abstract}

Keywords: Organization, Information System, E-Voting System, Personal Extreme Programming (PXP), Laravel

\begin{abstract}
Abstrak
Organisasi sendiri mempunyai struktur keanggotaan yang berfungsi untuk membagi tugas dari setiap individu dan setiap organisasi mempunyai pemimpin yang berfungsi untuk mengatur jalannya organisasi. Di Universitas XYZ terdapat berbagai macam organisasi yang dapat diikuti oleh seluruh mahasiswa. Ketua organisasi dipilih dari kegiatan pemilu yang diadakan setiap tahunnya guna melanjutkan tongkat estafet kepengurusan. Terdapat beberapa kendala yang dialami saat melakukan kegiatan pemilu yaitu, kegiatan pemilu dilakukan secara luring, dikarenakan kondisi pandemic sehingga kegiatan pemilu tidak dapat dilaksanakan, terdapat banyak surat suara yang tidak sah, dan juga proses perhitungan suara yang memakan waktu cukup lama. Selain kendala saat pemilu, kegiatan pemilu juga memakan biaya cukup banyak guna untuk mencetak surat suara dan sebagainya untuk melancarkan pemilu. Oleh karena itu, dilakukan penelitian ini yaitu dengan membangun sebuah sistem informasi e-voting. Sistem e-voting sendiri memiliki beberapa keunggulan dibandingkan dengan pemilu yang dilakukan secara luring. Diharapkan pada sistem e-voting dapat mengurangi adanya kesalahan yang dilakukan pada pemilu luring.Pada pengembangan sistem menggunakan metode Personal Extreme Programming (PXP) dengan menggunakan framework Laravel. Diharapkan sistem yang dibangun dapat membantu proses pemungutan suara dalam kegiatan pemilu di Universitas XYZ.
\end{abstract}

Kata Kunci: Organisasi, Sistem Informasi, Sistem E-Voting, Personal Extreme Programming, Laravel 

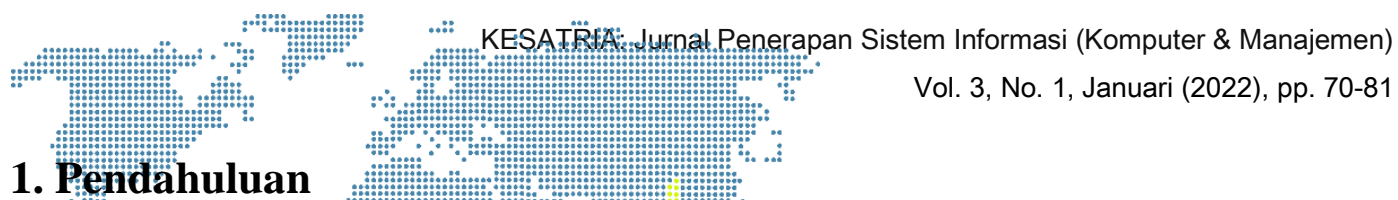

\section{. Tentahuluan}

Universitas XYZ merupakan perguruan tinggi negeri yang terdapat di kota Balikpapan

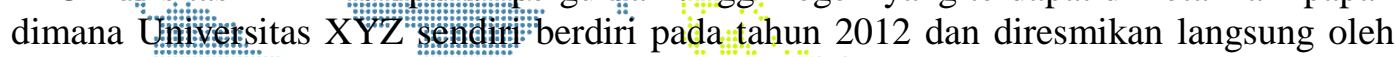

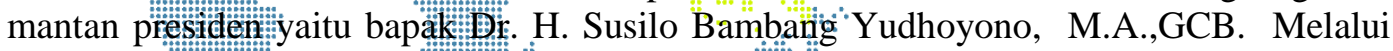

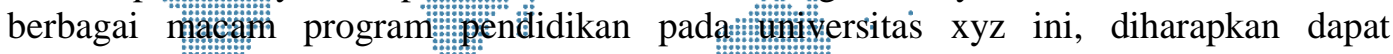

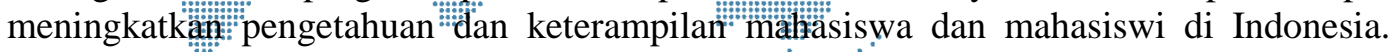
Selain mendapatkan pendidikan, mahasiswa Universitas XYZ dapat bergabung dengan organisasi mahasiswa. Pada setiap organisasi memiliki ketua organisasi yang berfungsi untuk mengatur jalannya organisasi tersebut. Untuk menentukan ketua organisasi baik dilakukan dengan kegiatan pemilu [1].

Saat kegiatan pemilu dilaksanakan seluruh mahasiswa yang mempunyai hak pilih dapat menentukan ketua organisasi. Untuk memilih ketua organisasi, mahasiswa diharuskan untuk datang ke Tempat Pemungutan Suara (TPS) yang disediakan panitia, mahasiswa diharuskan untuk mengantri dalam melakukan pemilihan. Untuk proses pemilihan dimana mahasiswa absen kemudian masuk ke dalam bilik suara dan memilih ketua organisasi selanjutnya mahasiswa memasukkan kertas pilihannya ke dalam kotak suara dan pada jari mahasiswa diberikan tinta sebagai bukti telah menggunakan hak pilih. Setelah proses pemilihan telah selesai, maka dilakukan perhitungan suara dimana suara terbanyaklah yang akan menjadi ketua organisasi tersebut. Namun dalam proses kegiatan pemilu dimana terdapat banyak kendala yang dihadapi, contohnya pada pemilu tahun 2019 yang dilakukan secara luring. Pada pemilu tahun 2019 kegiatan pemilu dilakukan selama 3 hari dengan total pengguna suara sebanyak 2055 mahasiswa, dan juga terdapat $118(7,91 \%)$ surat suara yang tidak sah dari total pengguna suara. Dari data tersebut dapat disimpulkan bahwa proses pemilu memiliki kerumitan dalam penyelenggaraannya dan memiliki kendala yang membuat proses pemilu tidak berjalan dengan baik baik dari segi efektifitas maupun efisiensi. Dalam perkembangan teknologi hingga saat ini memberikan banyak manfaat dikarenakan memberikan berbagai kemudahan dari segi akses maupun biaya. Dalam memanfaatkan teknologi informasi pada proses pemilihan umum akan membuat proses tersebut lebih efektif dan efisien dimana sebelumnya dilakukan secara luring maka dapat dilakukan secara daring dalam pemungutan suara.

Pemilu di Universitas XYZ dilakukan satu kali dari setiap tahun kepengurusan, akan tetapi untuk tahun ini kegiatan pemilu tidak dapat diselenggarakan dikarenakan adanya pandemic covid-19 dimana dibatasinya semua kegiatan yang berhubungan dengan adanya perkumpulan. Untuk di Universitas XYZ sendiri sangat terdampak virus covid-19 dimana seluruh kegiatan akademik maupun non akademik tidak dipersilahkan digelar secara luring. Terkhusus pada organisasi dimana program kerja yang telah dirancang dan ditetapkan akan diubah menjadi daring dalam proses penyelenggaraannya, dan dalam kegiatan pemilu pada tahun ini belum ada kepastian bagaimana cara menyelenggarakannya, sedangkan setiap tahun diharuskan untuk meregenerasi ketua organisasi yang ada. Pandemic sendiri tidak ada kepastian mengenai kapan akan berakhir. Dengan adanya permasalahan tersebut dimana kurangnya sistem dalam melakukan pemilihan secara daring maka diperlukan sistem informasi terkait $e$-voting guna untuk menangani permasalahan pemilu yang ada saat ini.

Penelitian yang dilakukan oleh Iisnaini dan Bagus Rizki tahun 2019 [2] mengatakan bahwa sistem informasi $e$-voting dapat membantu proses kegiatan pemilu di wilayah kampus. Aplikasi voting/electronic voting (e-voting) dianggap lebih efektif dan lebih efisien karena semua proses secara terkomputerisasi, memberikan kemudahan bagi pengguna untuk memilih calon, mempermudah dalam proses penghitungan suara dan hasil pemilihan bisa langsung diketahui secara cepat dan akurat dalam merealisasikan pemilu, sistem tersebut dapat membantu dalam melakukan perhitungan suara dan dapat mengurangi terjadinya suara tidak sah. Menurut penelitian [3] tentang teknologi $e$-voting memudahkan pemilih dalam suatu pemilihan umum untuk menggunakan hak pilihnya dengan menggunakan media elektronik dan internet. Dengan adanya $e$-voting diharapkan 

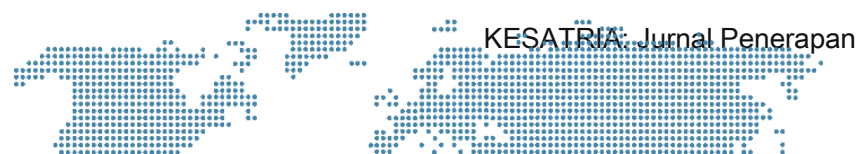

em Informasi (Komputer \& Manajemen)

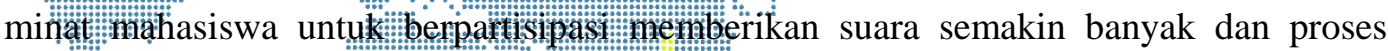
pengotahän suara semakkin cepat.

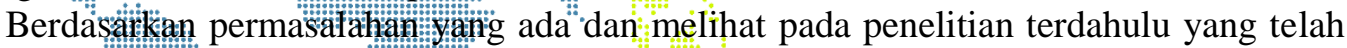

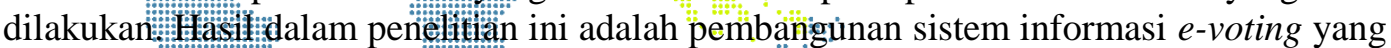

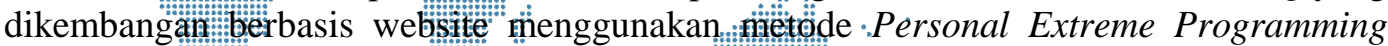

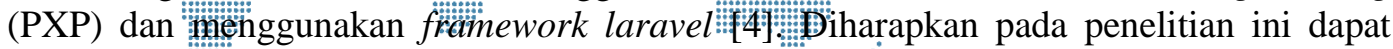
membantu pẹlaksanaan kegiatan pemilu dimana proses perhitungan suara secara manual dapat digantikan dengan perhitungan secara otomatis oleh sistem e-voting dan juga diharapkan surat suara tidak sah tidak terjadi lagi dengan adanya sistem $e$-voting. Sehingga dapat meningkatkan kualitas pemilu yang di berikan oleh Institut Teknologi Kalimantan kepada mahasiswa.

\section{Metodologi Penelitian}

Penelitian ini dilakukan pada Universitas XYZ yaitu membangun sistem informasi $e$ voting berbasis website yang menggunakan metode Personal Extreme Programming (PXP). Dalam tahapan penelitian ini disesuaikan dengan tahapan pada metode PXP, berikut merupakan tahapan yang dilakukan pada penelitian ini [5].

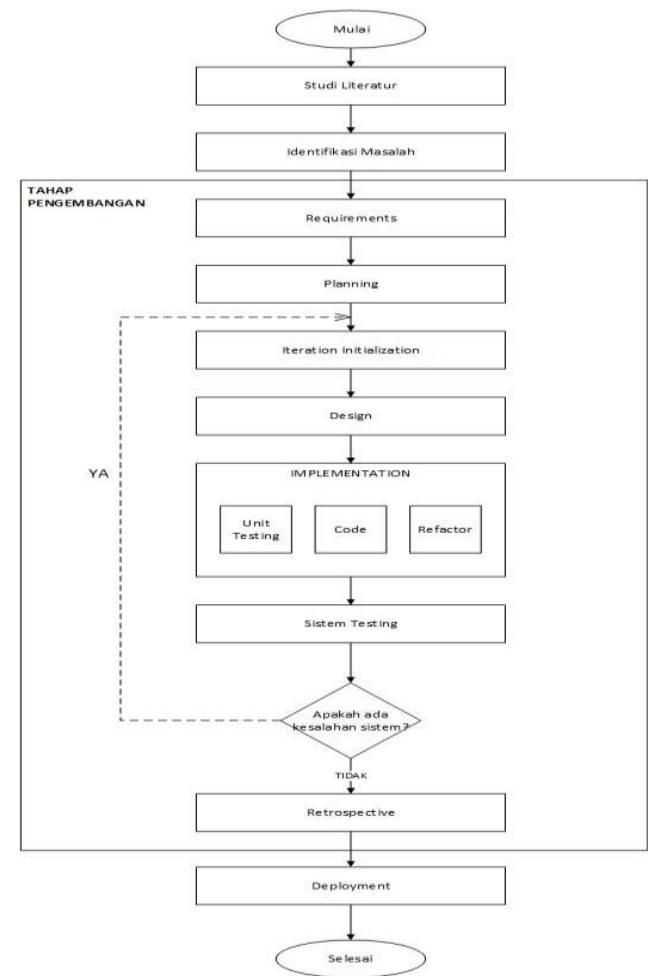

Gambar 1. Diagram Alir Penelitian

\subsection{Studi Literatur}

Pada proses studi literatur yaitu untuk mencari dasar teori yang mendukung dan memperkuat, serta memiliki keterkaitan dengan penelitian yang dilakukan. Hal ini dapat dilakukan dengan menggunakan berbagai sumber yaitu buku, jurnal, penelitian terdahulu yang berkaitan dengan sistem informasi, personal extreme programming (PXP) development, framework laravel, serta referensi penelitian terdahulu yang terkait.

\subsection{Identifikasi Masalah}

Dalam tahap identifikasi masalah yaitu menganalisa masalah yang terjadi pada Universitas XYZ, dimana masalah yang terjadi yaitu proses yang masih manual dalam melakukan proses voting atau pemungutan suara dengan tujuan mencapai kesepakatan 


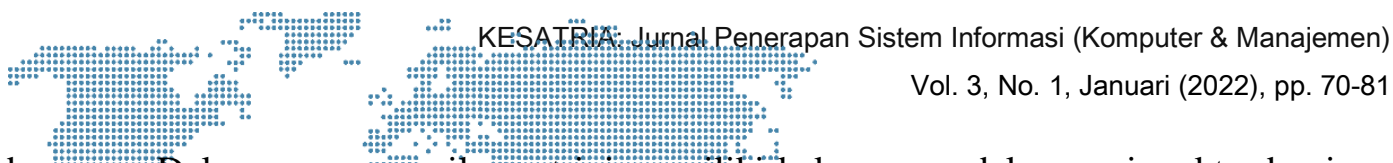

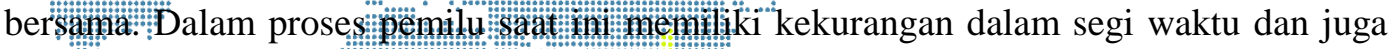

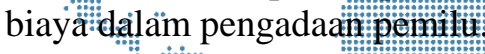

\subsection{Requitements}

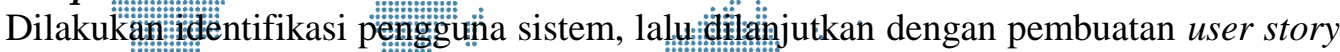
mengenai kebutuhan penggina akan sistem yang fi bangun. Untuk user story sendiri diberikan kepada pengguna sistem $e$-voting yaitu mahasiswa Universitas XYZ. Namun, dikarenakan terlalu banyak maka akan diberikan kepada pimpinan organisasi.

\subsection{Planning}

Pada tahap planning atau perencanaan yaitu tahapan ditentukannya fitur yang ingin disediakan di dalam sistem tersebut dan kegunaan masing-masing fitur tersebut dari setiap user. Dalam kegunaan fitur tersebut dibuat dalam bentuk use case [6] sebelum dilakukan pembangunan sistem. Dan selanjutnya adalah merancang jadwal pembangunan sistem.

\subsection{Iteration Initialization}

Dilakukan inisialisasi dari proses iterasi dalam pengembangan sistem e-voting. Iterasi ini berguna untuk membatasi pengerjaan agar lebih efisien dan menunjukkan progress yang dapat dilihat. Iterasi membagi pengembangan sistem menjadi beberapa unit kecil. Unit kecil tersebut masing-masing dikembangkan pada iterasi. Iterasi berjangka waktu 1-3 minggu, dan akan terus diulang sampai tahap pengembangan selesai dan tidak ditemukan permasalahan pada sistem.

\subsection{Design}

Pada tahapan design yaitu mendesain mulai dari tampilan sistem hingga pada database yang digunakan. Untuk tampilan sistem menggunakan mockup untuk mendesainnya dan untuk desain database menggunakan Entity Relationship Diagram (ERD) [7].

\subsection{Implementation}

Tahapan dilakukannya pengkodean sistem dengan kolaborasi bahasa markup HTML, bahasa pemrograman PHP dan framework laravel. Basis data akan menggunakan MySQL [8].

\subsection{System Testing}

Pengujian sistem sangat penting dilakukan untuk memastikan bahwa sistem yang telah dibuat bisa berjalan dengan baik sesuai dengan yang diharapkan. Selain itu pengujian juga dapat dilakukan untuk memberi pelatihan kepada user terkait cara penggunaan fitur-fitur yang terdapat di dalam sistem. Pengujian sistem dilakukan dengan menggunakan metode blackbox testing, dengan mengamati hasil eksekusi melalui data uji dan pengecekan fungsi fitur-fitur yang telah dibuat [9].

\subsection{Retrospective}

Dilakukan pengambilan kesimpulan terhadap sistem, apabila masih ada kesalahan maka akan dilakukan perbaikan mulai dari tahap iteration initialization. Tahapan ini merupakan kesimpulan dari metode yang digunakan apakah dapat membantu dalam proses pembuatan aplikasi dengan baik atau tidak.

\subsection{Deployment}

Deployment tersebut dilakukan setelah sistem tidak memiliki kesalahan ataupun bug yang ada pada sistem. Deployment merupakan tahapan rilis dari sebuah sistem dimana deployment sendiri bertujuan agar user dari sistem tersebut dapat menggunakan sistem $e$ voting tersebut. 


\section{Hasil dan Pembahasan}

Hâsill dản pembahăsan pada bagian ini merupakan penjelasan singkat mengenai hasil

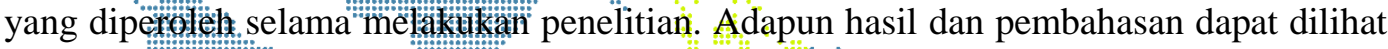
dalam subobab berikut.

\subsection{Requirements}

Pada tahap.ini dilakukan pembuatan user story mengenai kebutuhan dan fungsionalitas sistem terhälap user pengguna. Pada proses peneñtuan fungsionalitas sistem maka dilakukan wawancara terhadap pihak terkait. Berikut merupakan user story yang berhasil dibuat sesuai dengan kebutuhan.

Tabel 1. User Story

\begin{tabular}{|c|c|c|c|}
\hline \multirow{2}{*}{ Kode } & \multirow{2}{*}{ Persona } & \multicolumn{2}{|r|}{ User Story } \\
\hline & & I Want to & So that \\
\hline US-01 & Semua User & Login & $\begin{array}{l}\text { Saya dapat masuk ke dalam sistem dan } \\
\text { menggunakan fitur yang ada pada sistem }\end{array}$ \\
\hline US-02 & Semua User & Logout & Saya dapat keluar dari sistem \\
\hline US-03 & Super Admin & $\begin{array}{l}\text { Menambahkan akun admin } \\
\text { KPU }\end{array}$ & $\begin{array}{l}\text { Saya dapat membuatkan akun admin untuk } \\
\text { KM dan Himpunan }\end{array}$ \\
\hline US-04 & Super Admin & Mengedit akun admin KPU & $\begin{array}{l}\text { Saya dapat mengubah akun admin untuk KM } \\
\text { dan Himpunan }\end{array}$ \\
\hline US-05 & Super Admin & Menghapus akun admin KPU & $\begin{array}{l}\text { Saya dapat menghapus akun admin untuk } \\
\text { KM \& Himpunan }\end{array}$ \\
\hline US-06 & Super Admin & Menambahkan data prodi & Saya dapat menambahkan data prodi \\
\hline US-07 & Super Admin & Mengubah data prodi & Saya dapat mengubah data prodi \\
\hline US-08 & Super Admin & Menghapus data prodi & Saya dapat menghapus data prodi \\
\hline US-09 & Super Admin & $\begin{array}{l}\text { Menambahkan periode tahun } \\
\text { pemilu }\end{array}$ & $\begin{array}{l}\text { Saya dapat menambahkan periode tahun } \\
\text { pemilu sesuai dengan periode pemilu yang } \\
\text { akan diselenggarakan }\end{array}$ \\
\hline US-10 & Super Admin & $\begin{array}{l}\text { Mengaktifkan periode tahun } \\
\text { pemilu }\end{array}$ & $\begin{array}{l}\text { Saya dapat mengaktifkan periode tahun } \\
\text { pemilu }\end{array}$ \\
\hline US-11 & Super Admin & $\begin{array}{l}\text { Menghapus periode tahun } \\
\text { pemilu }\end{array}$ & Saya dapat menghapus periode tahun pemilu \\
\hline US-12 & Super Admin & $\begin{array}{l}\text { Menambahkan data contact } \\
\text { person }\end{array}$ & $\begin{array}{l}\text { Saya dapat menambahkan data contact } \\
\text { person }\end{array}$ \\
\hline US-13 & Super Admin & $\begin{array}{l}\text { Mengubah data contact } \\
\text { person }\end{array}$ & Saya dapat mengubah data contact person \\
\hline US-14 & Super Admin & $\begin{array}{l}\text { Menghapus data contact } \\
\text { person }\end{array}$ & Saya dapat menghapus data contact person \\
\hline US-15 & Admin KPU & $\begin{array}{l}\text { Menambahkan data calon } \\
\text { pemimpin }\end{array}$ & $\begin{array}{l}\text { Saya dapat menambahkan data calon } \\
\text { pemimpin }\end{array}$ \\
\hline US-16 & Admin KPU & $\begin{array}{l}\text { Mengubah data calon } \\
\text { pemimpin }\end{array}$ & Saya dapat mengubah data calon pemimpin \\
\hline US-17 & Admin KPU & $\begin{array}{l}\text { Menghapus data calon } \\
\text { pemimpin }\end{array}$ & Saya dapat menghapus data calon pemimpin \\
\hline US-18 & Admin KPU & $\begin{array}{l}\text { Menambahkan data } \\
\text { mahasiswa pemilih }\end{array}$ & $\begin{array}{l}\text { Saya dapat menambahkan data mahasiswa } \\
\text { yang berhak untuk memilih dalam pemilu }\end{array}$ \\
\hline US-19 & Admin KPU & $\begin{array}{l}\text { Mengimport data mahasiswa } \\
\text { pemilih }\end{array}$ & $\begin{array}{l}\text { Saya dapat import data mahasiswa pemilih } \\
\text { dari file excel ke dalam sistem }\end{array}$ \\
\hline US-20 & Admin KPU & $\begin{array}{l}\text { Mengubah data maahsiswa } \\
\text { pemilih }\end{array}$ & $\begin{array}{l}\text { Saya dapat mengubah data mahasiswa } \\
\text { pemilih }\end{array}$ \\
\hline US-21 & Admin KPU & $\begin{array}{l}\text { Menghapus data mahasiswa } \\
\text { pemilih }\end{array}$ & $\begin{array}{l}\text { Saya dapat menghapus data mahasiswa } \\
\text { pemilih }\end{array}$ \\
\hline US-22 & Admin KPU & $\begin{array}{l}\text { Melihat status mahasiswa } \\
\text { pemilih }\end{array}$ & $\begin{array}{l}\text { Saya dapat melihat status mahasiswa pemilih, } \\
\text { apakah sudah memilih atau belum }\end{array}$ \\
\hline US-23 & Admin KPU & $\begin{array}{l}\text { Membuat token untuk } \\
\text { mahasiswa pemilih }\end{array}$ & $\begin{array}{l}\text { Saya dapat membuatkan token untuk } \\
\text { mahasiswa pemilih untuk hak akses ke dalam } \\
\text { sistem }\end{array}$ \\
\hline US-24 & Admin KPU & $\begin{array}{l}\text { Mereset token untuk } \\
\text { mahasiswa pemilih }\end{array}$ & $\begin{array}{l}\text { Saya dapat mereset token untuk mahasiswa } \\
\text { pemilih apabila token tersebut tidak valid }\end{array}$ \\
\hline US-25 & Admin KPU & $\begin{array}{l}\text { Menampilkan grafik hasil } \\
\text { pemilu KM maupun } \\
\text { Himpunan }\end{array}$ & Saya dapat melihat grafik hasil pemilu \\
\hline
\end{tabular}




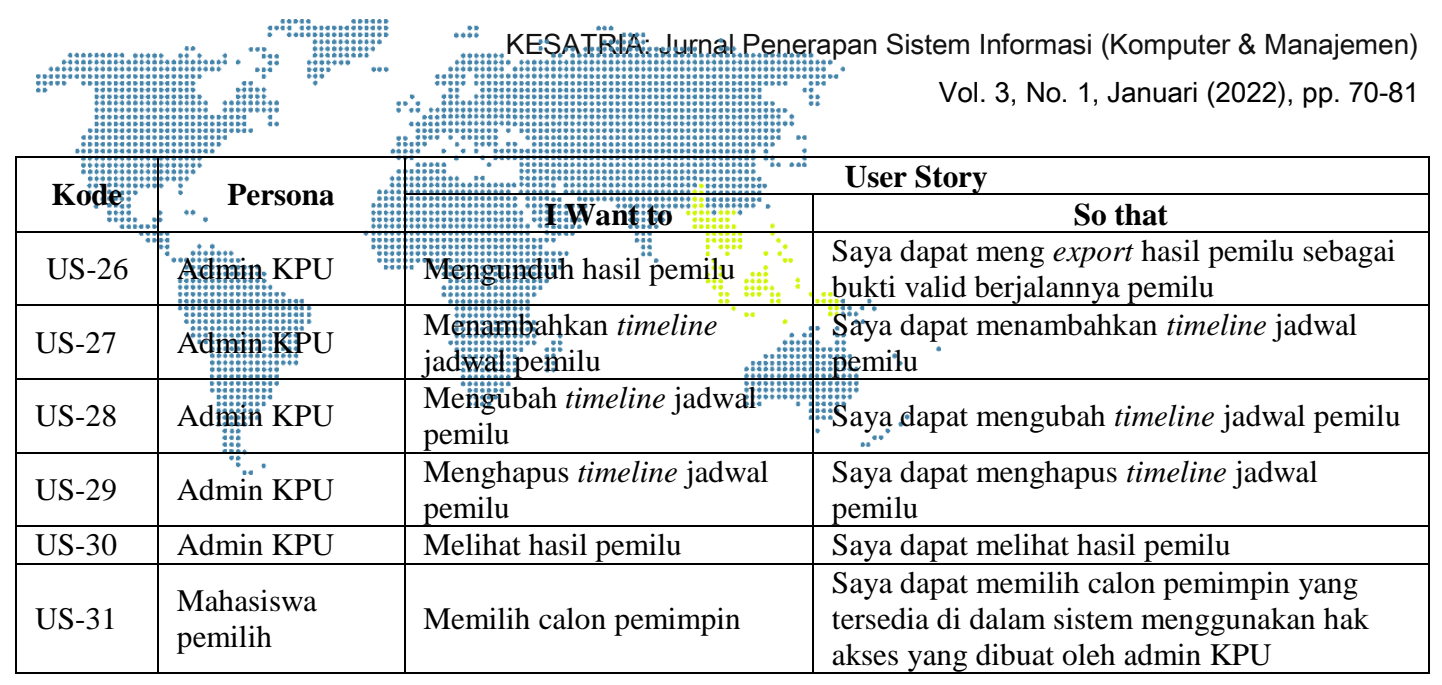

\subsection{Planning}

Pada tahap ini dilakukan perencanaan dari user story yang telah dibuat yaitu melakukan penjadwalan untuk realisasi user story ke dalam sistem e-voting. Pada user story yang dibuat dibagi menjadi beberapa bagian dan dikelompokkan sesuai dengan user. Berikut iterasi yang telah dibuat sesuai dengan user story.

Tabel 2. Iterasi 1

\begin{tabular}{|c|c|c|c|}
\hline Kode & User & User Story & Estimasi \\
\hline US-01 & Super Admin & Login & \multirow{14}{*}{10 Hari } \\
\hline US-02 & Super Admin & Logout & \\
\hline US-03 & Super Admin & Menambahkan akun admin KPU & \\
\hline US-04 & Super Admin & Mengubah akun admin KPU & \\
\hline US-05 & Super Admin & Menghapus akun admin KPU & \\
\hline US-06 & Super Admin & Menambahkan data prodi & \\
\hline US-07 & Super Admin & Mengubah data prodi & \\
\hline US-08 & Super Admin & Menghapus data prodi & \\
\hline US-09 & Super Admin & Menambahkan periode tahun pemilu & \\
\hline US-10 & Super Admin & Mengaktifkan periode tahun pemilu & \\
\hline US-11 & Super Admin & Menghapus periode tahun pemilu & \\
\hline US-12 & Super Admin & Menambahkan data contact person & \\
\hline US-13 & Super Admin & Mengubah data contact person & \\
\hline US-14 & Super Admin & Menghapus data contact person & \\
\hline
\end{tabular}

Tabel 3. Iterasi 2

\begin{tabular}{|c|l|l|l|}
\hline Kode & \multicolumn{1}{|c|}{ User } & \multicolumn{1}{c|}{ User Story } & \multirow{2}{*}{ Estimasi } \\
\hline US-15 & Admin KPU & Menambahkan data calon pemimpin & \\
\hline US-16 & Admin KPU & Mengubah data calon pemimpin & \\
\hline US-17 & Admin KPU & Menghapus data calon pemimpin & \\
\hline US-18 & Admin KPU & Menambahkan data mahasiswa pemilih & \multirow{2}{*}{ 15 Hari } \\
\hline US-19 & Admin KPU & Mengimport data mahasiswa pemilih & \\
\hline US-20 & Admin KPU & Mengubah data mahasiswa pemilih & \\
\hline US-21 & Admin KPU & Menghapus data mahasiswa pemilih & \\
\hline US-23 & Admin KPU & Membuat token mahasiswa pemilih & \\
\hline US-24 & Admin KPU & Mereset token mahasiswa pemilih & \\
\hline US-27 & Admin KPU & Menambahkan timeline jadwal pemilu & \\
\hline US-28 & Admin KPU & Mengubah timeline jadwal pemilu & \\
\hline US-29 & Admin KPU & Menghapus timeline jadwal pemilu & \\
\hline
\end{tabular}

Tabel 4. Iterasi 3

\begin{tabular}{|l|l|l|l|}
\hline \multicolumn{1}{|c|}{ Kode } & \multicolumn{1}{|c|}{ User } & \multicolumn{1}{c|}{ User Story } & \multirow{2}{*}{ Estimasi } \\
\cline { 1 - 2 } US-31 & Mahasiswa pemilih & Memilih calon pemimpin & \multirow{2}{*}{5 Hari } \\
\hline US-22 & Mahasiswa pemilih & Melihat status mahasiswa pemilih & \\
\hline US-25 & Mahasiswa pemilih & Menampilkan grafik hasil pemilu & \\
\hline US-26 & Mahasiswa pemilih & Mengunduh hasil pemilu & \\
\hline US-30 & Mahasiswa pemilih & Melihat hasil pemilu & \\
\hline
\end{tabular}




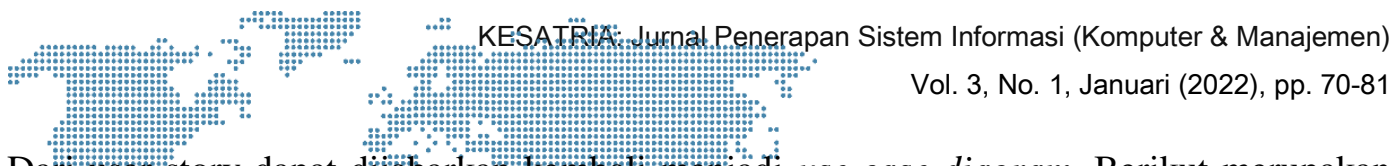

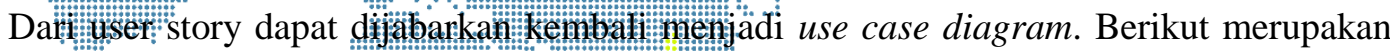

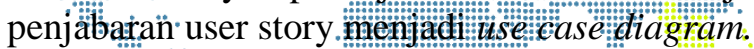

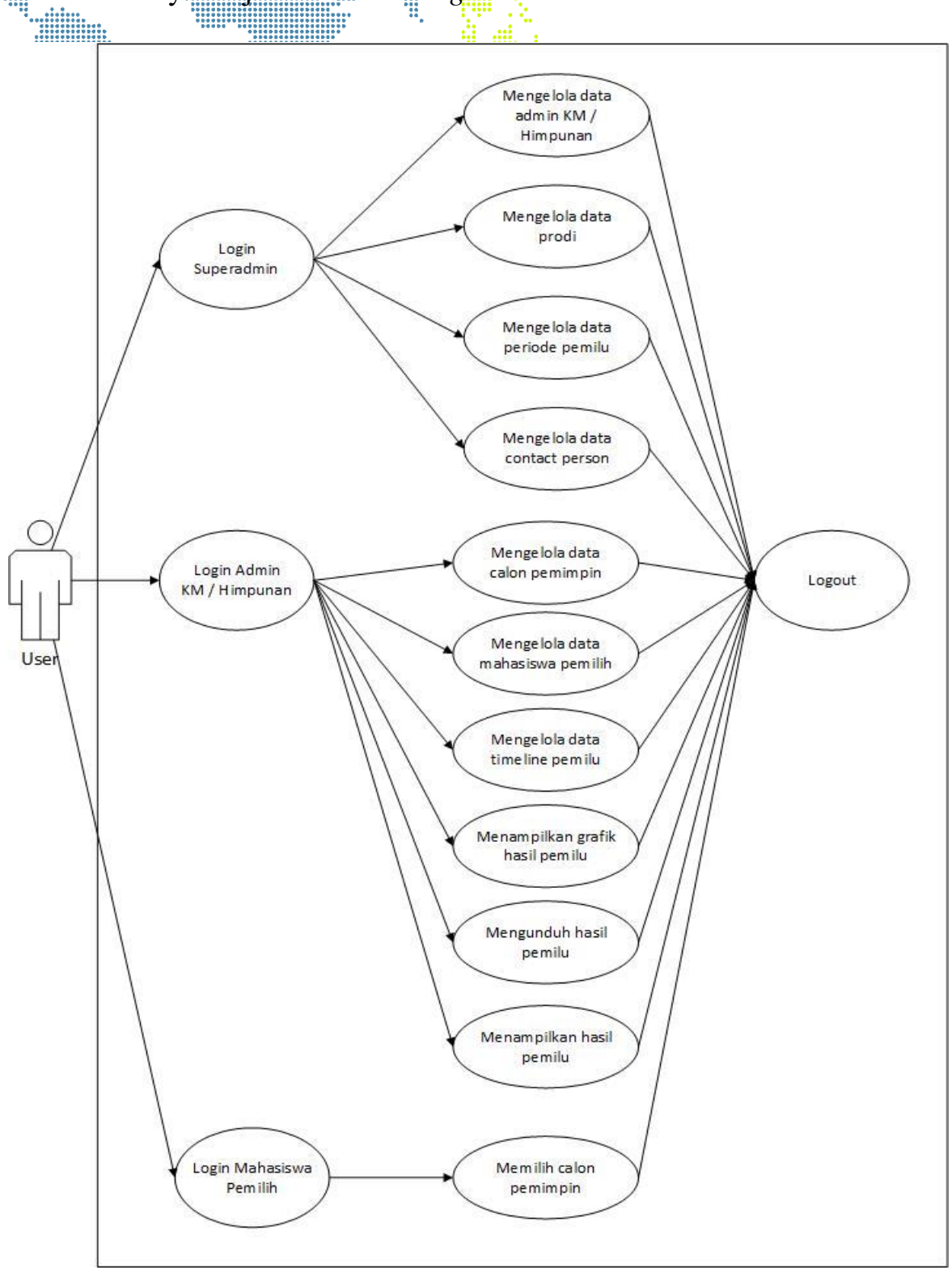

\subsection{Iteration Initialization}

Gambar 2. Use Case Diagram

Iteration initialization menandakan permulaan setiap iterasi. Pada pembangunan sistem $e$-voting terdapat 3 iterasi yang dibagi sesuai dengan user penggunanya. Setiap iterasi dikerjakan dalam waktu 1-3 minggu. Iterasi 1 dimulai pada 1 Juni 2021 hingga 11 Juni 2021 menghabiskan waktu sekitar 10 hari untuk menyelesaikan iterasi 1. Developer mengerjakan login, logout, user story mengelola data admin pemilu, mengelola data prodi, dan juga mengelola data contact person. Setelah menyelesaikan iterasi 1 selanjutnya melakukan pembangunan pada iterasi 2 dimana iterasi 2 dikerjakan dalam waktu 15 hari dan dimulai pada 15 Juni 2021 hingga 30 Juni 2021. Fitur yang diselesaikan oleh developer yaitu mengelola data calon pemimpin, mengelola data mahasiswa pemilih, mengelola data timeline pemilu, menampilkan grafik hasil pemilu, mengunduh hasil pemilu, menampilkan hasil pemilu. Setelah menyelesaikan iterasi 2 selanjutnya melakukan pembangunan pada iterasi terakhir yaitu iterasi 3. Iterasi 3 dikerjakan dalam waktu 5 hari dan dimulai pada 5 Juli 2021 hingga 10 Juli 2021. Fitur yang diselesaikan developer yaitu memilih calon pemimpin. 

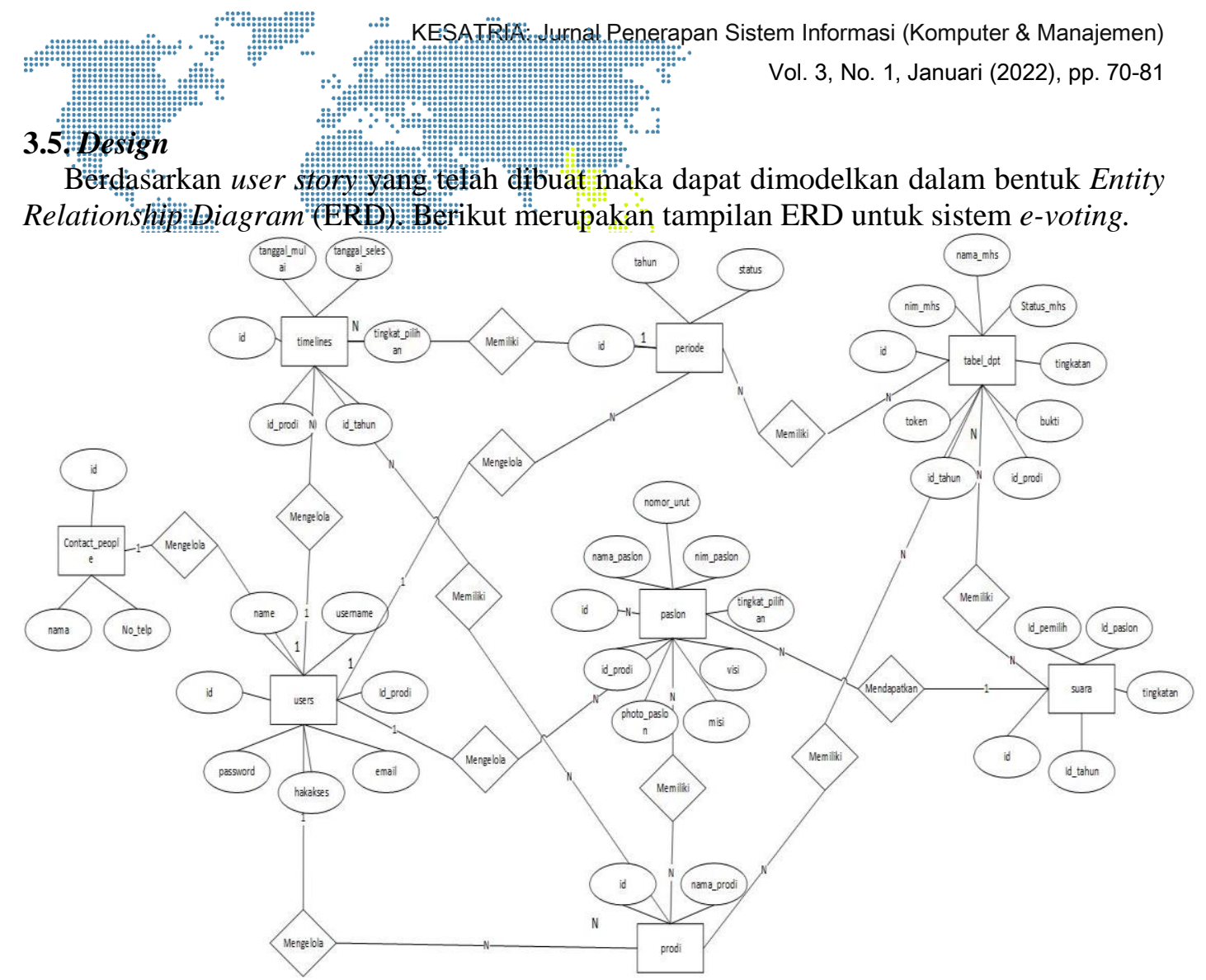

Gambar 3. Entity Relationship Diagram

Gambar 3 merupakan Entity Relationship Diagram (ERD) dari sistem informasi $e$ voting yang terdiri dari 7 tabel, yaitu tabel user, tabel prodi, tabel timeline, tabel suara, tabel DPT (dewan pemilih tetap) atau mahasiswa pemilih, tabel paslon, dan tabel periode. Selanjutnya masing-masing tabel akan dijelaskan sebagai berikut :

a) Tabel user memiliki relasi one to many ke tabel timeline, tabel periode, tabel DPT, tabel prodi, dan juga tabel paslon. Sehingga tabel user dapat mengelola data pada tabel timeline, periode, DPT, prodi, dan juga paslon.

b) Tabel prodi memiliki relasi many to many ke tabel timeline, tabel DPT, dan juga tabel paslon. Sehingga pada tabel prodi memiliki data yang digunakan pada tabel timeline, tabel DPT, dan tabel paslon

c) Tabel paslon memiliki relasi one to many pada tabel suara. Sehingga tabel paslon memiliki data suara begitu pula tabel suara di dapatkan dari tabel paslon.

d) Tabel suara memiliki relasi many to many pada tabel dpt dan juga tabel periode. Sehingga tabel suara memiliki data yang digunakan oleh tabel dpt dan juga tabel periode

e) Tabel timeline memiliki relasi one to one dengan tabel periode. Sehingga tabel timeline memiliki data yang dimiliki oleh data periode.

Setelah dibuatnya Entity Relationship Diagram (ERD) maka selanjutnya dibuatkan mockup atau design user interface untuk sistem e-voting. Mockup tersebut dibuat menggunakan software balsamiq. Adapun tampilan mockup dapat dilihat pada gambar berikut. 


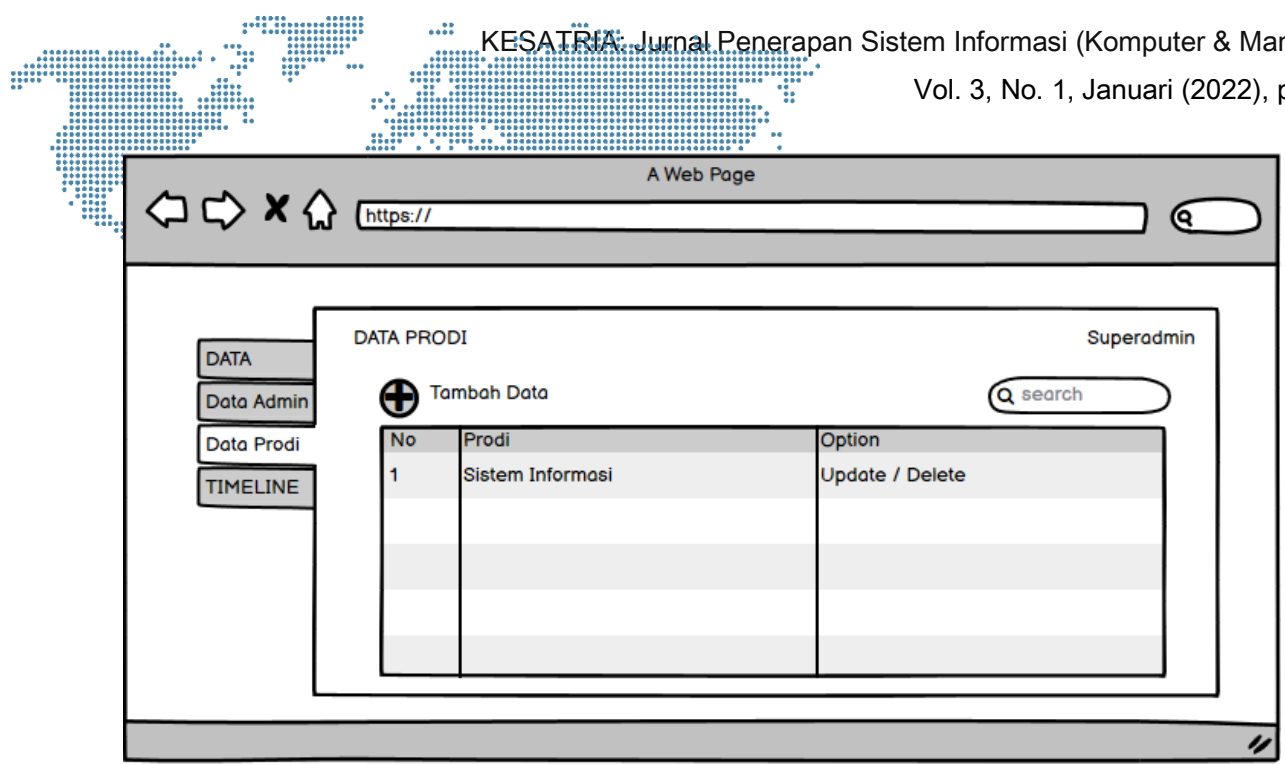

Gambar 4. Mockup Data Prodi

Gambar 4 merupakan design tampilan pada menu data prodi dengan user pengguna super admin. Terdapat kolom no, prodi dan juga option untuk mengelola data tersebut. Begitu juga fitur search untuk mencari suatu data dengan cepat.

\subsection{Implementation}

Tahap implementasi dilakukan dengan penulisan kode program menggunakan metode Model, View, dan Controller yang merupakan elemen dari framework laravel. Pengkodean dibuat berdasarkan perancangan Entity Relationship Diagram (ERD) dan juga desain tampilan sistem yang telah dibuat. Pengkodean program dilakukan pada semua fitur iterasi. Berikut merupakan hasil implementasi pengkodean menjadi sebuah tampilan sistem $e$-voting.

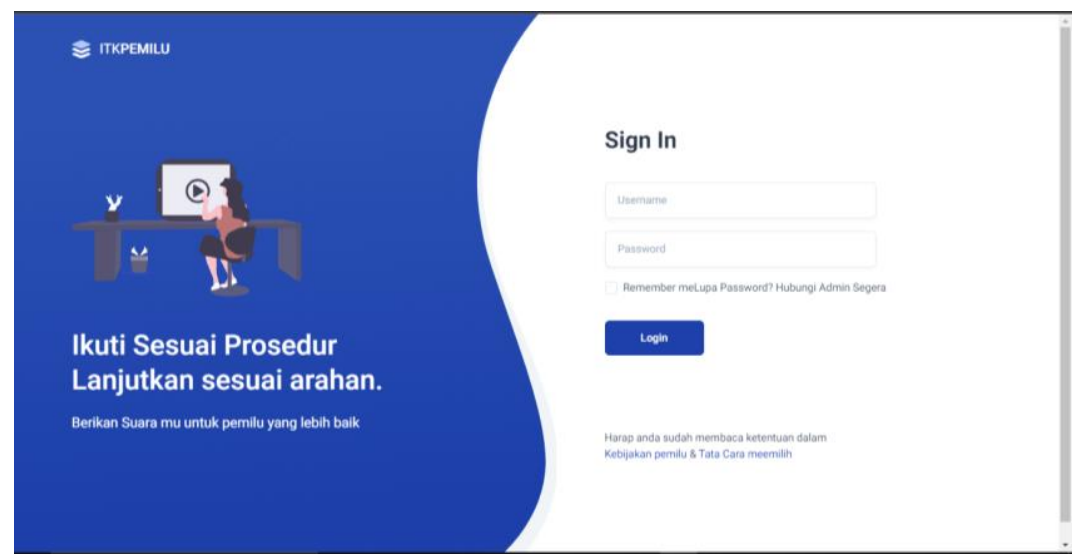

Gambar 5. Tampilan Sistem Login

Gambar 5 merupakan tampilan halaman awal untuk masuk ke dalam sistem e-voting, dimana user diharuskan untuk mengisi username dan password pada kolom username dan password yang telah disediakan oleh sistem. Untuk user login dapat disesuaikan oleh user pengguna masing-masing. 


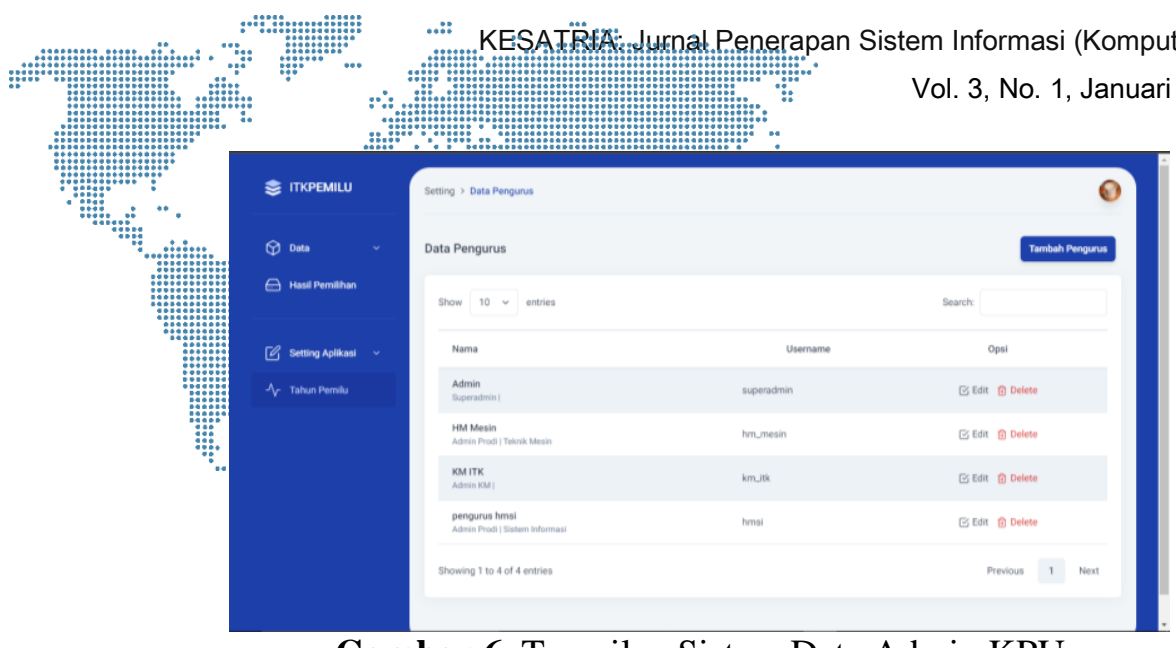

Gambar 6. Tampilan Sistem Data Admin KPU

Gambar 6 merupakan tampilan user pengurus atau admin KPU. Superadmin dapat mengelola data pengurus pada tiap prodi yang ingin melangsungkan pemilu. Untuk membuat user admin KPU, pihak KPU harus menghubungi superadmin terlebih dahulu untuk meminta agar dibuatkan akun pengurus.

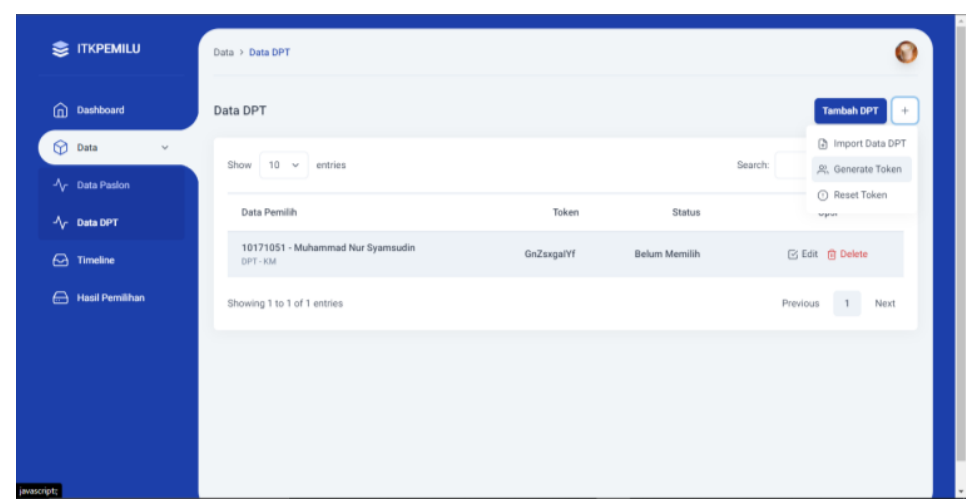

Gambar 7. Tampilan Sistem Data DPT

Gambar 7 merupakan tampilan pada halaman data DPT. Dalam menu data DPT terdapat berbagai fitur salah satunya adalah generate token yang berfungsi untuk membuatkan user login yang akan digunakan oleh DPT atau mahasiswa pemilih untuk masuk ke dalam sistem e-voting. Generate token membuat suatu huruf acak. Pada menu data DPT berisi data DPT yang sebelumnya telah ditambahkan, dan terdapat juga menu untuk generate token dimana token tersebut akan dikirimkan melalui email masingmasing dan pada token tersebut dapat digunakan untuk login ke dalam sistem.

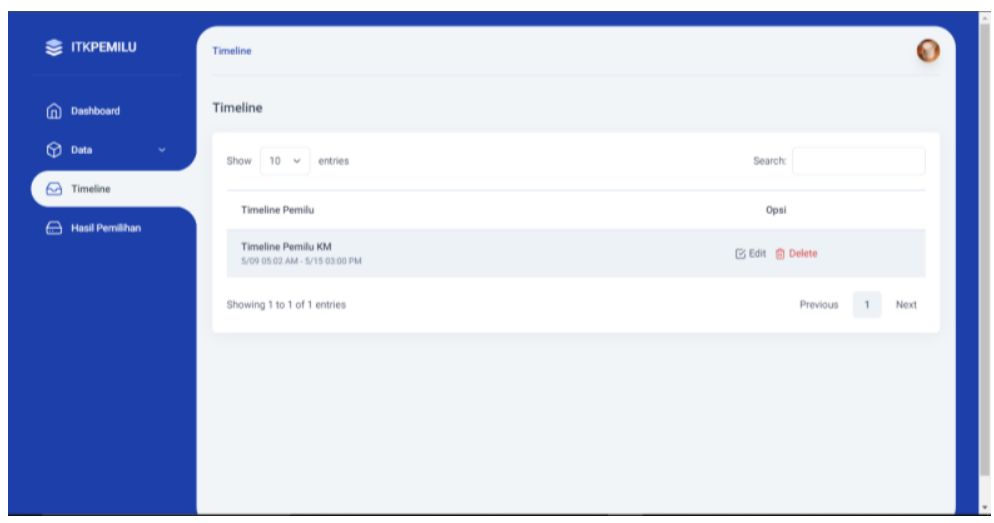

Gambar 8. Tampilan Sistem Timeline Pemilu 


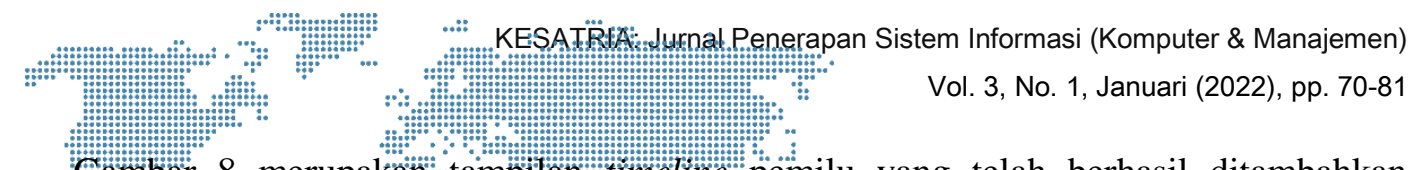

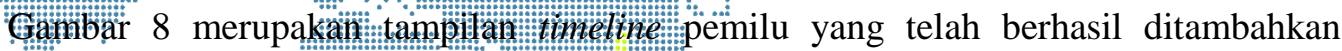

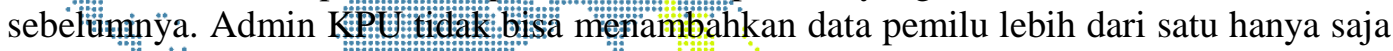

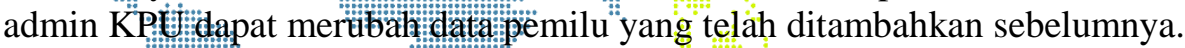

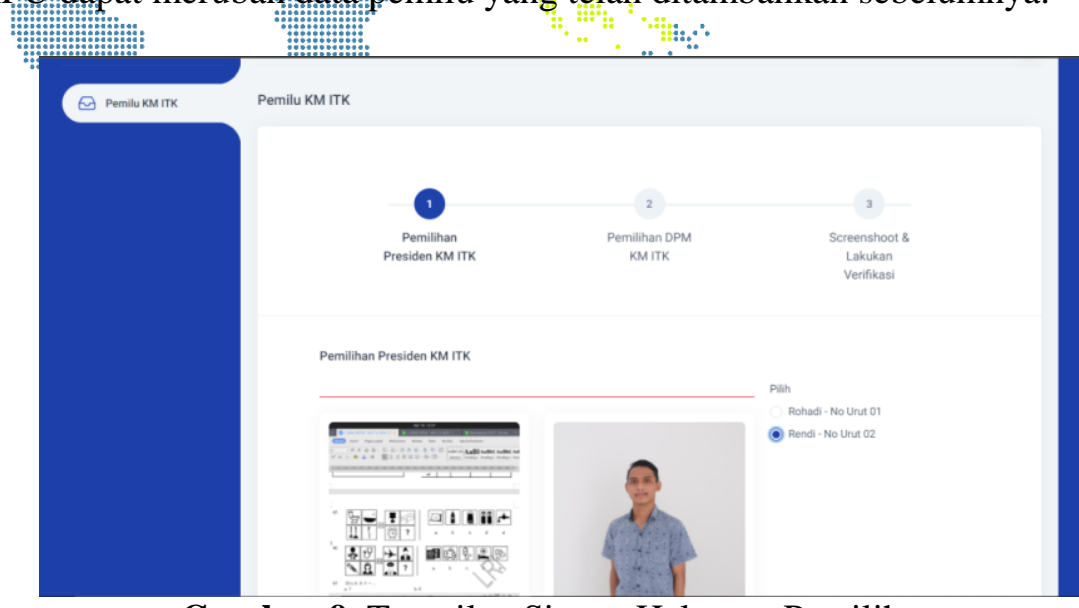

Gambar 9. Tampilan Sistem Halaman Pemilihan

Gambar 9 merupakan tampilan untuk hak akses DPT atau mahasiswa pemilih, dimana DPT akan langsung diarahkan pada menu pemilihan calon pemimpin. Pada Langkah pertama pada pemilihan yaitu melakukan pemilihan pada calon pemimpin, setelah selesai menggunakan hak pilih maka akan diarahkan oleh sistem untuk tahap verifikasi dengan cara upload file screeshoot hasil telah menggunakan hak pilih.

\subsection{System Testing}

Setelah melakukan tahap implementation, dilakukan system testing atau pengujian sistem informasi kepada klien. System testing dilakukan dengan ketua organisasi yang memipin Universitas XYZ saat ini. Hasil dari tahap system testing disajikan dalam bentuk dokumen User Acceptance Testing (UAT). Terdapat 31 user story yang akan dilakukan testing dan hasil menunjukkan $100 \%$ dari total user story yang telah dilakukan testing berhasil dijalankan dengan baik. Berikut merupakan salah satu bukti testing yang telah dilakukan.

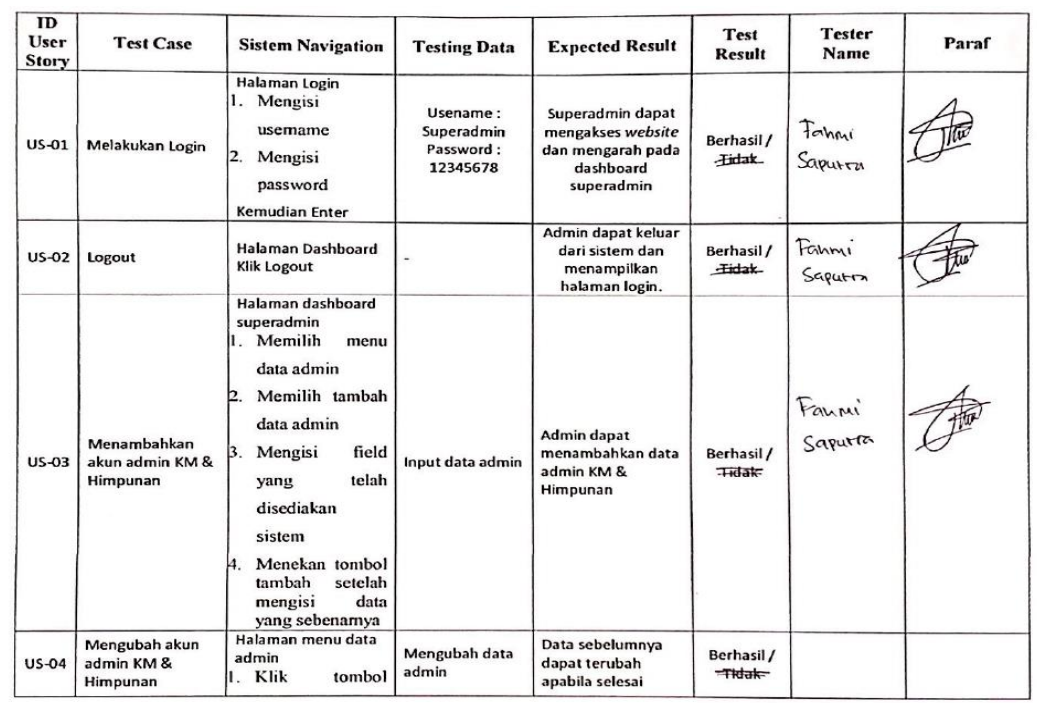

Gambar 10. Hasil System Testing

\subsection{Deployment}

Tahap selanjutnya yang dilakukan setelah semua iterasi telah dikerjakan dan tidak ada perbaikan sistem yaitu melakukan deployment pada Sistem Informasi E-Voting yang telah 


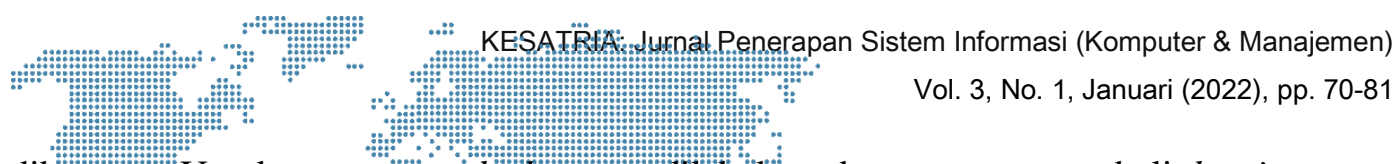

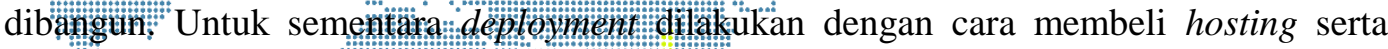
domäm däri penyedia proses hosimg yaitu dengan mempersiapkan source code, database sistem e-voting, beserta ownain: hosting selingga pengguna dapat menggunakan sistem tersebut dimanapun mereka berada domain tersebut ke dalan:"'Web browser. Entule kedepannya sistem e-voting akan menggunakạ: hosting pada server dari pihak kampús...."

\section{Kesimpulan}

Berdasarkan penelitian yang telah dilaksanakan maka didapatkan kesimpulan yaitu, Sistem informasi $e$-voting yang telah dibangun telah dilakukan sistem testing oleh user dan juga telah dilakukan user acceptance testing dengan hasil segala menu yang disediakan di dalam sistem berjalan dengan semestinya. Sistem informasi $e$-voting yang telah dibangun dapat menyelesaikan permasalahan yang ada pada penelitian ini, dikarenakan lebih efisien dan juga lebih efektif dibandingkan dengan pemilu offline.

\section{Daftar Pustaka}

[1] Gritzalis, D. (2002). Secure Electronic Voting New Trends New Threats. Athens : Dept. Of Informatics Athens University Of Economics and Business and Data Protection Commission Of Greece.

[2] Isnaini, B. R. (2019). Aplikasi E-Vote Pemilihan Presiden Badan Eksekutif Mahasiswa (Bem) Amik Dian Cipta Cendekia Bandar Lampung Berbasis Web. Onesismik/Vol.2 No.2 .

[3] Muliawan, I. W. (2012). Internet Voting System Untuk DIASPORA Indonesia. Fakultas Ilmu Komputer dan Teknologi Informasi.

[4] Shawn, M. (2012). Laravel Stater "The definitive intoduction to the Laravel PHP web development framework". Brimingham B3 2PB: UK: Open Source Community Distilled.

[5] Dzhurov, Y. K. (2009). Personal Extreme Programming - An Agile Process for Autonomous Developers. Faculty of Mathematics and Informatics Sofia University.

[6] Dhawiyanti, S., \& Wahono, R. (2003). Pengantar Unified Modeling. Ilmu Komputer , pp. 113.

[7] Hala, K. A.-M. (2015). Extracting Entity Relationship Diagram (ERD) From Relational Database Schema. International Journal of Database Theory and Application Vol.8, No.3 , pp.15-26.

[8] Solichin, A. (2016). Pemrograman Web dengan PHP dan MySQL. Jakarta: Budi Luhur.

[9] Fatmawati. (2016). Perancangan Sistem Informasi Pemesanan Katering Berbasis Web Pada Rumah 